\title{
Mechanisms and Structural Determinants of HIV-1 Coat Protein, gp41-Induced Neurotoxicity
}

\author{
D. Cory Adamson, ${ }^{1,2}$ Kathy L. Kopnisky, ${ }^{1}$ Ted M. Dawson, ${ }^{1,2}$ and Valina L. Dawson ${ }^{1,2,3}$ \\ Departments of ${ }^{1}$ Neurology, ${ }^{2}$ Neuroscience, and ${ }^{3}$ Physiology, Johns Hopkins University School of Medicine, Baltimore, \\ Maryland 21287
}

\begin{abstract}
Of the individuals with human immunodeficiency virus type 1 (HIV-1) infection, 20-30\% will develop the neurological complication of HIV-associated dementia (HAD). The mechanisms underlying HAD are unknown; however, indirect immunologically mediated mechanisms are theorized to play a role. Recently, the HIV-1 coat protein gp41 has been implicated as a major mediator of HAD through induction of neurocytokines and subsequent neuronal cell death. Using primary mixed cortical cultures from neuronal nitric oxide synthase (NOS) null $\left(\mathrm{nNOS}^{-1-}\right.$ ) mice and immunological NOS null (iNOS ${ }^{-/}$) mice, we establish iNOS-derived $\mathrm{NO}$ as a major mediator of gp41 neurotoxicity. Neurotoxicity elicited by gp41 is markedly attenuated in $\mathrm{iNOS}^{-1-}$ cultures compared with wild-type and $\mathrm{nNOS}^{-1-}$ cultures. The NOS inhibitor L-nitroarginine methyl ester is neuroprotective in wild-type and $\mathrm{nNOS}^{-/-}$cultures, confirming the role of iNOS-derived NO in gp41 neurotoxicity. Confirming that iNOS $^{-1-}$ cultures lack iNOS, gp41 did not induce iNOS in iNOS ${ }^{-1-}$ cultures, but it markedly induced iNOS
\end{abstract}

The most common cause of neurological disease in young adults in the United States today is human immunodeficiency virus type 1 (HIV-1) infection (Janssen et al., 1992). Among HIV-1infected children and adults, 20-30\% will develop HIVassociated dementia (HAD) during the course of their illness (Navia et al., 1986; Price et al., 1988). The mechanisms by which HIV-1 causes HAD are not known. However, indirect mechanisms are most likely to be involved in the pathogenesis of HAD (Wesselingh et al., 1993). There is increasing evidence that HIV-1 infection in the brain is associated with significant neuronal loss as well as loss and complexity of dendritic arborization, loss of synaptic densities, and vacuolization of dendritic spines (Everall et al., 1991; Masliah et al., 1992; Wiley et al., 1992). Although neuronal damage occurs in HAD, it is not attributable

\footnotetext{
Received July 22, 1998; revised Oct. 13, 1998; accepted Oct. 19, 1998.

This work was supported by United Public Health Service Grants T32 NS 07392 (to D.C.A. and K.L.K.) and NS 26643 (to V.L.D.). T.M.D. is an Established Investigator of the American Heart Association and is supported by the Paul Beeson Faculty Scholar Award in Aging Research. We thank Dr. Allen Mandir for his suggestions regarding our statistical analyses, and Brian Hoffman for his technical help with generating our mice cultures.

Under an agreement between the Johns Hopkins University and Guilford Pharmaceuticals, T.M.D. and V.L.D. are entitled to a share of sales royalty received by the University from Guilford. T.M.D. and the University also own Guilford stock, and the University stock is subject to certain restrictions under University policy.

The terms of this arrangement are being managed by the University in accordance with its conflict of interest policies.

Correspondence should be addressed to Dr. Valina L. Dawson, Department of Neurology, Johns Hopkins University School of Medicine, 600 N. Wolfe Street, Carnegie 2-214, Baltimore, MD 21287.

Copyright (C) 1998 Society for Neuroscience $\quad 0270-6474 / 98 / 190064-08 \$ 05.00 / 0$
}

in wild-type and nNOS ${ }^{-1-}$ cultures. We elucidate the region of gp41 that is critical for iNOS induction and neuronal cell death by monitoring iNOS induction with overlapping peptides spanning gp41. We show that the $\mathrm{N}$-terminal region of gp41, which we designate as the neurotoxic domain, induces iNOS protein activity and iNOS-dependent neurotoxicity at picomolar concentrations in a manner similar to recombinant gp41 protein. Our experiments suggest that gp41 is eliciting the induction of iNOS through potential cell surface receptors or binding sites because the induction of iNOS is dose dependent and saturable and occurs at physiologically relevant concentrations. These data confirm that the induction of iNOS by gp 41 and the production of $\mathrm{NO}$ are primary mediators of neuronal damage and identify a neurotoxic domain of gp41 that may play an important role in HAD.

Key words: HIV-1; HIV-associated dementia; neurotoxicity; gp41; immunological nitric oxide synthase; nitric oxide to direct infection by HIV-1. Localization of HIV-1 in the CNS is almost exclusively in blood-derived macrophages, microglia, and multinucleated giant cells (Wiley et al., 1986; Rosenblum, 1990; Watkins et al., 1990). A paradox seems to exist between the small number of productively HIV-1-infected cells and the resulting HAD and pathological brain deficits. Recent studies indicate that HIV-1-infected cells in the CNS are making proinflammatory cytokines that induce a local immune or cytokine reaction, ultimately leading to neuronal dysfunction and neuronal cell death (Merrill and Chen, 1991). Colocalization studies show expression of mRNA for pro-inflammatory cytokines such as TNF- $\alpha$ and immunological nitric oxide synthase (iNOS) and for macrophage inflammatory protein $-1 \alpha$ (MIP- $1 \alpha)$ and MIP- $1 \beta$ in uninfected cells that are spatially localized near HIV-1-infected cells (Nuovo and Alfieri, 1996; Seilhean et al., 1997).

Various viral proteins have been implicated as mediators of neurodegeneration in HAD (Sabatier et al., 1991; Werner et al., 1991; Dawson et al., 1993). A particularly attractive candidate protein is the HIV-1 coat protein gp160. gp160 is cleaved by intracellular proteases into gp120 and gp41 (Willey et al., 1988; Haseltine, 1989; Earl et al., 1991), which remain noncovalently associated. gp120 is soluble and can be shed from infected cells, and it is thought to be quickly degraded by extracellular proteases. gp 41 is an integral membrane protein that remains inserted in the membrane of infected cells (Willey et al., 1988, 1996; Bird et al., 1990). Early studies demonstrated the synergistic activity of gp120 with glutamate that results in neurotoxicity mediated by stimulation of NMDA receptor (Brenneman et al., 
1988; Lipton et al., 1991) and subsequent activation of neuronal nitric oxide synthase (nNOS) (Dawson et al., 1993). Although gp120 may contribute to neurodegeneration in HAD, it is unlikely to be the sole or primary insult in HAD because a number of host and viral factors have been shown to modulate or contribute to HAD. In addition, gp120 has not been detected in the brains of individuals affected with HIV-1 (Hill et al., 1993; Toggas et al., 1994; Adamson et al., 1996b). In contrast, gp41 is readily detected in the brains of $\mathrm{HIV}-1$-infected individuals (Kure et al., 1990a,b; Dickson et al., 1993), and the levels of gp41 correlate with the severity and progression of HAD in adults (Adamson et al., 1996b, 1998; Rostasy et al., 1998) and children (Dickson et al., 1989). Recombinant gp41, in a manner identical to vaccinia virus-expressed gp41 (Koka et al., 1995a,b), efficiently induces the expression of pro-inflammatory cytokines, including TNF- $\alpha$, interleukin $1 \beta$ (IL-1 $\beta$ ), platelet-activating factor (PAF), and iNOS, in both human and rodent cultures (Merrill et al., 1992; Koka et al., 1995a,b), as well as IL-10 in human monocytes (Barcova et al., 1998). gp41 is active in the mid-nanomolar range, consistent with the levels that are readily detected in HIV-1infected brain tissue (Glass et al., 1995).

We recently observed a correlation between gp41 protein levels, iNOS expression. and severity and rate of progression of HAD (Adamson et al., 1996b, 1998). We showed that gp41 induces a cascade of events that is toxic to primary neuronal cultures through NO-dependent mechanisms. In the present study we examined the detailed mechanisms and structural determinants regulating NO mediation of gp41 neurotoxicity.

\section{MATERIALS AND METHODS}

Cell cultures. For the murine culture experiments, primary cortical cultures were prepared from gestational day 16 fetal wild-type, nNOS ${ }^{-1-}$, and iNOS $^{-1-}$ mice in a procedure modified from that described previously (Dawson et al., 1996). The genetic background of nNOS ${ }^{-1-}$ and iNOS $^{-/-}$mice originated from crosses between 129/SVev and C57B6 parental strains. Wild-type cultures were obtained from both $129 / \mathrm{SVev}$ and C57B6 mice. We did not observe any difference in the susceptibility to gp41 toxicity in either 129/SVev or C57B6 wild-type mice (data not shown). Thus, all data shown for wild-type mice are a mixture of data from both 129/SVev and C57B6 mice. Briefly, the cortex was dissected and the cells were dissociated by trituration in modified Eagle's medium (MEM), 20\% horse serum, $25 \mathrm{~mm}$ glucose, and $2 \mathrm{~mm}$ L-glutamine after a $30 \mathrm{~min}$ digestion in $0.027 \%$ trypsin/saline solution (Life Technologies, Gaithersburg, MD). The cells were plated on $15 \mathrm{~mm}$ multiwell plates coated with polyornithine. Cells were maintained in MEM, $10 \%$ horse serum, $25 \mathrm{~mm}$ glucose, and $2 \mathrm{~mm}$ L-glutamine in an $8 \% \mathrm{CO}_{2}$ humidified $37^{\circ} \mathrm{C}$ incubator. Cultures were treated on day 5 with $100 \mathrm{~nm}$ recombinant HIV-1 gp41 ${ }_{\text {III B }}$ (amino acids 1 through 241; Intracel, Cambridge, MA), examined, and harvested over a $7 \mathrm{~d}$ period. Peptides were added in the presence or absence of L-nitro-arginine ( $\mathrm{N}-\mathrm{Arg}$ ), L-nitroarginine methyl ester (L-NAME), and/or L-arginine (L-Arg). This model was chosen because it eliminates the use of mitotic inhibitors that may interfere with the induction of cytokines and to allow the co-culture of neurons and glia so that the neurons would not be receiving inappropriate signals from mature glia that may interfere with the neuronal-glial signaling (Dawson et al., 1993; Samdani et al., 1997). Mixed neuronal/glial rodent cultures were similarly obtained and prepared from fetal rats at gestational day 16 . After $7 \mathrm{~d}$ of maturation, these cultures were exposed to one of each of the peptide fragments (100 nM) spanning the entire extracellular domain of HIV-1 gp $41_{M N}$ (National Institute of Allergy and Infectious Diseases AIDS Research and Reference Reagent Program, Rockville, MD). On the basis of our immunoblot data, the highly active peptide 4 and inactive peptide 12 were subsequently used to assess the dose-response relationship and time course of iNOS induction. The specificity of peptide 4 was further assessed via the use of a purified peptide of the same forward and backward sequence generated at the Johns Hopkins University Department of Biological Chemistry Peptide Synthesis Laboratory.

Immunoblot analysis. For immunoblot analysis of iNOS, equivalent amounts of cell lysate prepared from the murine and rodent culture cells were separated on a $10 \%$ SDS-PAGE gel (Bio-Rad, Hercules, CA) in Tris-glycine buffer under reducing conditions. After electrophoresis, proteins were electroblotted onto nitrocellulose and incubated with antimacNOS antibody (1:500; Transduction Laboratories, Lexington, KY). Immunoblots were developed by enhanced chemoluminescence (Kirkegaard \& Perry Laboratories, Gaithersburg, MD). For iNOS proteinpositive controls, rodent glial cultures stimulated with $100 \mathrm{ng} / \mathrm{ml}$ lipopolysaccharide for $24 \mathrm{hr}$ produced a robust signal on immunoblot at $130 \mathrm{kDa}$.

Neurotoxicity assessment. The cultured murine and rat cells were exposed to recombinant gp41 and gp41 peptides as described previously (Adamson et al., 1996b). Toxicity was assayed as described previously (Gonzalez-Zulueta et al., 1998). Briefly, total and dead cells were counted by computer-assisted microscopic examination after staining of all nuclei with $1 \mu \mathrm{g} / \mathrm{ml}$ Hoescht 33342 and staining of dead cell nuclei with $7 \mu \mathrm{M}$ propidium iodide. Glial nuclei fluoresce at a different intensity than neuronal nuclei and can be gated out. Percentage of cell death was determined as the ratio of live to dead cells as compared with the percentage of cell death in control wells to account for cell death attributable to mechanical stimulation of the cultures. At least two separate experiments using four separate wells were performed with a minimum of $15,000-20,000$ neurons counted per data point. We consider this cell counting method to be the gold standard in determining cell death. This method allows assessment of the majority of the culture well, which eliminates potential observer bias (Gonzalez-Zulueta et al., 1998).

NOS activity assay. After culture media was removed from the cells, $100 \mu \mathrm{l}$ of sample buffer (50 mm Tris-HCl, pH 7.4, $1 \mathrm{~mm}$ EGTA, and $1 \mathrm{~mm}$ EDTA) was added to each well. Cells were homogenized in the wells, collected, and centrifuged at $15,000 \times g$ at $4^{\circ} \mathrm{C}$. The supernatant was then incubated with excess $\left[{ }^{3} \mathrm{H}\right]$ arginine and $1 \mathrm{~mm}$ NADPH in the presence or absence of $5 \mathrm{~mm} \mathrm{~N}$-Arg and in the presence or absence of $1 \mu \mathrm{M} \mathrm{CaCl}_{2}$ for $15 \mathrm{~min}$ at room temperature. The reaction was stopped with $20 \mathrm{~mm}$ HEPES, pH 5.5, plus 2 mM EDTA, and loaded into 5 inch chromatography columns (Evergreen Scientific, Los Angeles, CA) containing an anion exchange resin. Flow-through was collected and radioactivity was counted. Reactions without $\mathrm{CaCl}_{2}$ detected only calcium-independent NOS isoform (iNOS) activity, whereas reactions with $\mathrm{CaCl}_{2}$ allowed calcium-dependent activity (nNOS and endothelial NOS) to be assessed. Subtraction of the latter activity from the former revealed the true amount of iNOS, calcium-independent activity. Reactions with N-Arg, a competitive inhibitor of all NOS isoforms, revealed background radioactivity in the assay.

\section{RESULTS}

\section{Neuronal cultures from iNOS ${ }^{-/-}$animals are resistant to gp41 neurotoxicity}

In primary cerebral cortical cultures from fetal rats, $100 \mathrm{nM}$ gp41 kills $50-60 \%$ of neurons after $7 \mathrm{~d}$ of continuous treatment. gp41-induced cell death is markedly reduced by NOS inhibitors (Adamson et al., 1996b). To evaluate the source of NO generation causing gp41 neurotoxicity, we examined gp41-mediated cell death in primary neuronal cultures from wild-type mice versus mice lacking the gene for $\mathrm{nNOS}\left(\mathrm{nNOS}^{-/-}\right)$and mice lacking the gene for iNOS (iNOS ${ }^{-/-}$). We showed previously that gp41 can induce iNOS in rat neuronal cultures. In wild-type cortical cultures gp41 begins to induce iNOS at approximately day 5 of continuous exposure and through day 7 of treatment (Fig. 1A). gp41 has no effect on astrocyte proliferation in these mixed cultures (data not shown). Although we did not determine the cell type in which iNOS is expressed, it is likely to be expressed in both astrocytes and microglia. Accompanying the increase in iNOS protein is gp41-mediated neurotoxicity that is blocked by $\mathrm{N}$-Arg, and its protective effect is reversed by the NOS substrate L-Arg, as reported previously in rat cultures (Adamson et al., 1996b). Typically $0-10 \%$ of neurons die in control-treated cultures over the $7 \mathrm{~d}$ treatment period (data not shown). In addition, the absolute number of neurons did not change significantly in control-treated cultures. However, the non-neuronal cells approximately double in both gp41 and control cultures because of the 

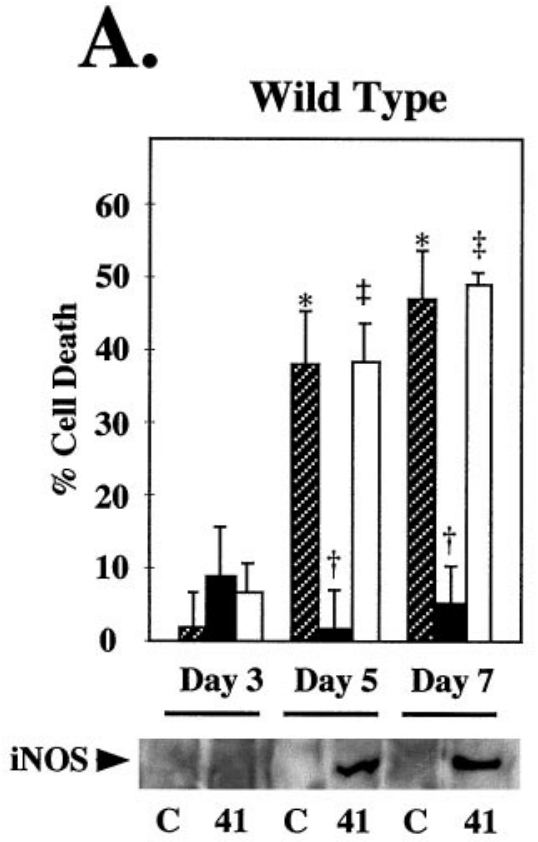

B.

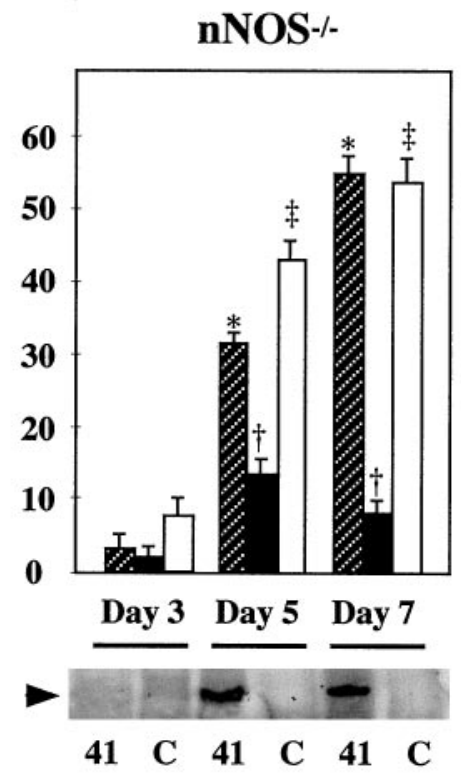

C.

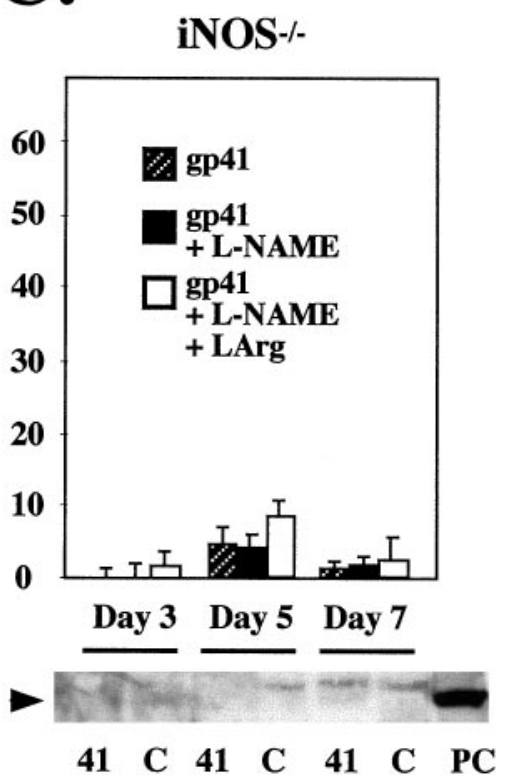

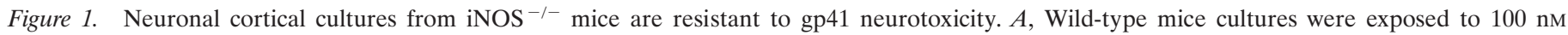

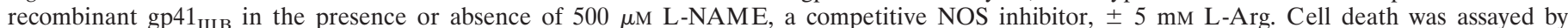

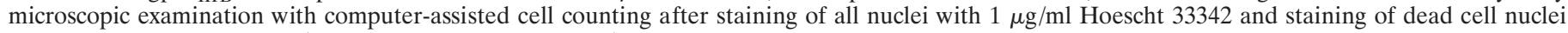

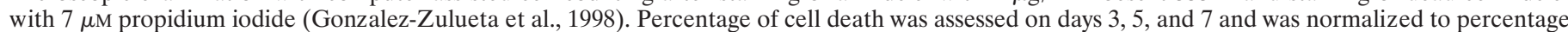

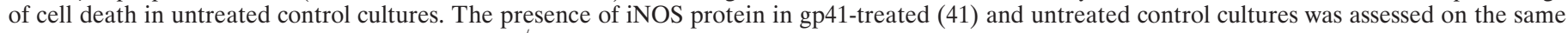

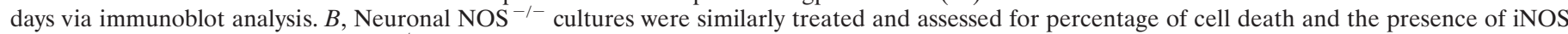

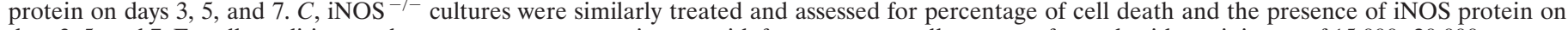

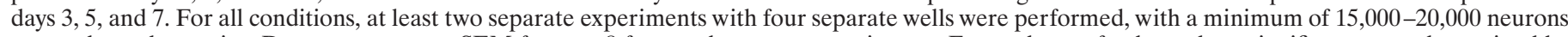

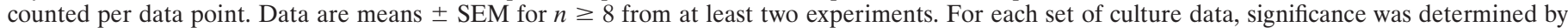

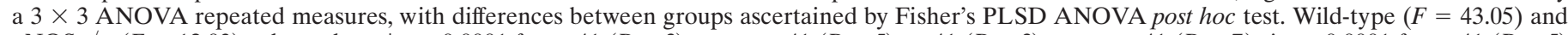

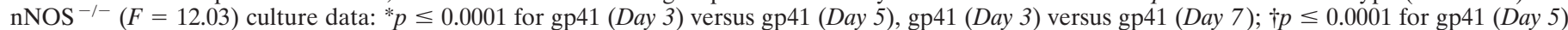

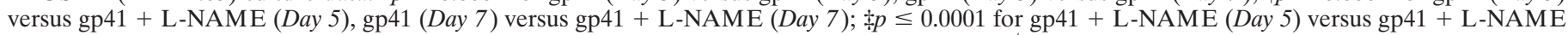
+ LArg (Day 5), gp41 + L-NAME (Day 7) versus gp41 + L-NAME + LArg $($ Day 7$)$. iNOS ${ }^{-/-}$culture data: $F=0.34(p=0.85)$.

lack of mitotic inhibitors (data not shown). gp41 induces the expression of iNOS in nNOS $^{-/-}$cultures in a manner that is indistinguishable from that of wild-type animals (Fig. 1B). Cortical cultures from $\mathrm{nNOS}^{-1-}$ mice are not protected against gp41-mediated neurotoxicity. As in wild-type mice cultures, $\mathrm{N}$-Arg blocks gp41 neurotoxicity, and this protection is reversed by excess substrate L-Arg (Fig. $1 B$ ). In cultures from iNOS ${ }^{-/-}$ mice, gp41 fails to induce the expression of iNOS as assessed by Western blot analysis (Fig. 1C). The 50-60\% cell death induced by gp41 in wild-type and nNOS ${ }^{-1-}$ cultures is almost completely abolished in iNOS $^{-1-}$ cultures (Fig. 1C). Thus, iNOS-derived $\mathrm{NO}$ is a major mediator and source of gp41-induced neurotoxicity.

\section{Epitope mapping of gp41 induction of iNOS}

To identify the structural determinants and critical region of gp41 that are potentially responsible for the induction of iNOS, we examined the ability of a number of overlapping peptides spanning the region of gp41 from the gp120/gp41 junction to the transmembrane domain of gp41 (Fig. $2 A$ ). We show that a number of peptides are capable of inducing iNOS (Fig. $2 B$ ), including peptides $2-4,6-11,13$, and 15 . Peptide 4 is the most potent inducer of iNOS. Peptide 1, which is part of the fusion domain of gp41, fails to induce iNOS as well as peptides 5, 12, 14, and 16 (Fig. 2B). Because a number of peptides spanning the entire extracellular domain of gp41 were found to induce iNOS, we conducted dose-response relationships for all of the active pep- tides in an attempt to identify the most active region of gp41 capable of inducing iNOS (Table 1). Peptides 2-4 were found to induce iNOS at a gp41 concentration of $1 \mathrm{pM}$, whereas all other peptides failed to induce iNOS at this concentration. Based on this set of data we have designated amino acids 530-559, which are contained within peptides $2-4$, as the neurotoxic domain of gp41 (Fig. 3).

\section{Characterization of the neurotoxic domain of gp41}

Because peptide 4 was found to be the most potent inducer of iNOS within the neurotoxic domain of gp41, we elected to further study peptide 4-mediated induction of iNOS and its relationship to gp41-mediated neurotoxicity. We first examined dose-response relationships of peptide 4 induction of iNOS by Western blot analysis and NOS catalytic activity as assessed by $\left[{ }^{3} \mathrm{H}\right]$ arginine to $\left[{ }^{3} \mathrm{H}\right]$ citrulline conversion (Fig. 4). Peptide 4 maximally induces iNOS at $100 \mathrm{~nm}$, as assessed by Western blot analysis, which parallels the induction of calcium-independent NOS catalytic activity. Peptide 4 fails to influence calcium-dependent NOS catalytic activity (data not shown). To control for possible nonspecific effects caused by possible contaminants in the peptide synthesis, we also examined in more detail peptide 12 , an inactive peptide identified in our initial screen that was synthesized and purified in a manner identical to peptide 4. Peptide 12 fails to induce iNOS at a concentration ranging from $100 \mathrm{pm}$ to $100 \mathrm{~nm}$ as assessed by both Western blot analysis for iNOS and calciumindependent NOS catalytic activity (Fig. 4B). Peptide 12 also fails 
A.
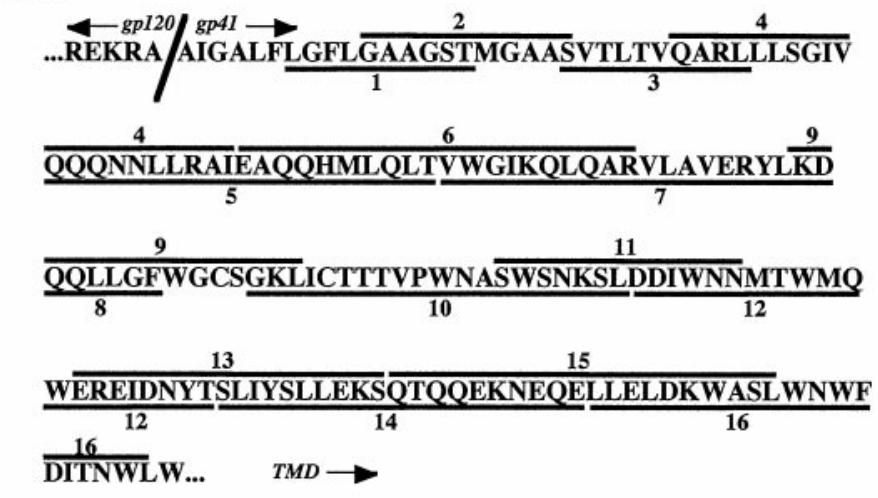

B.
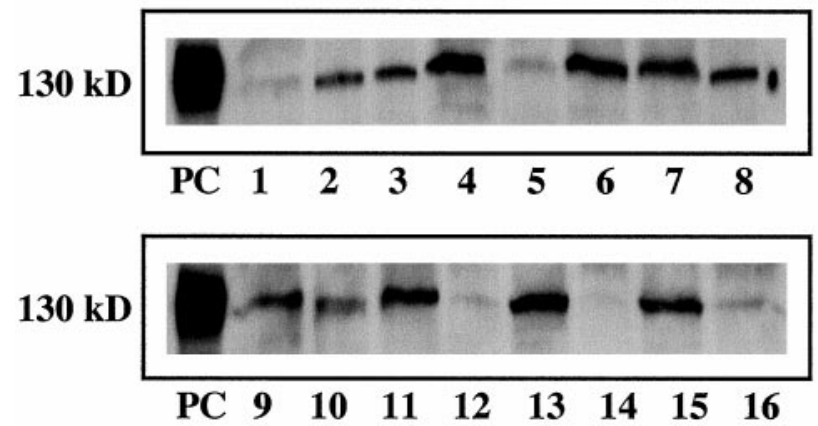

Figure 2. Epitope mapping of gp41 induction of iNOS reveals a number of regions in the extracellular domain of gp41 capable of inducing iNOS. $A$, A number of overlapping peptides (1-16) spanning the region of gp41 from the gp120/gp41 junction (slash seen to the left of peptide 1) to the transmembrane domain $(T M D)$ of gp41 were obtained. $B$, Rodent mixed cortical cultures were exposed to $100 \mathrm{~nm}$ each peptide, harvested on day 7 , and assessed for iNOS protein via immunoblot analysis. Positive controls $(P C)$ were obtained from rodent glial cultures stimulated with 100 $\mathrm{ng} / \mathrm{ml}$ lipopolysaccharide.

to influence calcium-dependent NOS catalytic activity (data not shown). We next evaluated the time course of induction of iNOS by peptide 4 (Fig. $4 C$ ). Peptide 4 begins to induce iNOS at day 3 , with maximal effects occurring at day 7 as assessed by Western blot analysis. There is a slight delay in the induction of NOS catalytic activity because NOS catalytic activity is not detected until day 5 of peptide 4 treatment. NOS catalytic activity is blocked by the NOS inhibitor L-NAME, and this inhibition of NOS catalytic activity is reversed by excess substrate L-Arg. The inactive peptide 12 fails to induce iNOS as assessed by Western blot analysis and NOS catalytic activity at all days examined (Fig. $4 D$ ). The dose-response and time course relationships of iNOS induction by peptide 4 closely parallel those as described previously for full-length recombinant gp41 (Adamson et al., 1996b). To further assess the specificity of the induction of iNOS by peptide 4, and to control for possible nonspecific effects such as contaminants in the synthesis and purification of the peptides, and to control for amino acid composition and charge, we obtained peptide 4 from another peptide synthesis facility and also synthesized it in the reverse direction. Peptide 4 from the alternative source potently induces iNOS in a manner identical to its counterpart, and the reverse peptide fails to induce iNOS (Fig. 5). Thus, the induction of iNOS by peptide 4 does not seem to be attributable to nonspecific effects.

\begin{tabular}{|c|c|c|c|c|c|c|}
\hline $\begin{array}{l}\text { gp41 } \\
\text { peptide }\end{array}$ & $1 \mathrm{pm}$ & $10 \mathrm{pm}$ & $100 \mathrm{pm}$ & $1 \mathrm{nM}$ & $10 \mathrm{~nm}$ & $100 \mathrm{~nm}$ \\
\hline 1 & 0 & 0 & 0 & 0 & 0 & 0 \\
\hline 2 & + & + & ++ & nd & nd & ++ \\
\hline 3 & + & + & ++ & nd & nd & ++ \\
\hline 4 & + & + & ++ & +++ & ++++ & +++++ \\
\hline 5 & 0 & 0 & 0 & 0 & 0 & 0 \\
\hline 6 & 0 & 0 & 0 & nd & nd & +++ \\
\hline 7 & 0 & + & ++ & nd & nd & +++ \\
\hline 8 & 0 & 0 & + & nd & nd & ++ \\
\hline 9 & 0 & 0 & 0 & nd & nd & ++ \\
\hline 10 & 0 & 0 & + & nd & nd & ++ \\
\hline 11 & 0 & 0 & 0 & nd & nd & +++ \\
\hline 12 & 0 & 0 & 0 & 0 & 0 & 0 \\
\hline 13 & 0 & 0 & + & nd & nd & ++++ \\
\hline 14 & 0 & 0 & 0 & 0 & 0 & 0 \\
\hline 15 & 0 & 0 & 0 & nd & nd & ++ \\
\hline 16 & 0 & 0 & 0 & 0 & 0 & 0 \\
\hline
\end{tabular}

Primary cortical cultures were exposed to overlapping peptides spanning the region of gp41 from the gp120/gp41 junction to the transmembrane domain of gp41, and the induction of iNOS was determined by Western blot analysis. Relative values for induction of iNOS were determined by optical density scanning of the iNOS band. 0 , No detectable iNOS protein; + to ++++ represent increasing intensity; nd, not determined. Data represent duplicate experiments.

\section{NOS inhibitors block neuronal cell death elicited by a gp41 neurotoxic domain peptide}

To establish the physiological relevance of the induction of iNOS by peptide 4 in neuronal cultures, we examined the ability of peptide 4 to cause neuronal killing in primary neuronal cultures. Peptide 4 begins to kill neurons at day 5 of treatment, which is consistent with the induction of NOS catalytic activity at this same time point (Fig. 6). Peptide 4-mediated neurotoxicity occurs through the full course of treatment, with maximal effects observed on day 7 . Neurotoxicity elicited by peptide 4 is blocked by L-NAME, and the protective effect of L-NAME is reversed by L-Arg (Fig. 6A). The inactive peptide 12 fails to elicit cell death at day 1 through day 7 (Fig. $6 B$ ).

\section{DISCUSSION}

Our study using primary neuronal cultures from $\mathrm{iNOS}^{-/-}$and $\mathrm{nNOS}^{-/-}$mice clarifies considerably the role of NO in gp41mediated neurotoxicity of cortical neurons. Previous studies have implicated NO as a mediator of gp41 neurotoxicity based on the neuroprotective properties of NOS inhibitors (Adamson et al., 1996b). iNOS was believed to be the source of NO because gp41 potently induces the expression of iNOS (Adamson et al., 1996b). Despite these data indicating NO and iNOS in gp41 neurotoxicity, questions could be raised that these studies are based on the use of drugs that may elicit nonspecific effects and that the induction of iNOS is an epiphenomenon that is unrelated to the toxicity of gp41. The use of mice lacking the gene for nNOS and iNOS overcomes many of these problems. The pronounced attenuation of gp41 neurotoxicity in $\mathrm{iNOS}^{-/-}$cortical cultures and the preservation of gp41 neurotoxicity in $\mathrm{nNOS}^{-1-}$ cortical cultures establishes a major role for iNOS and NO in gp41 neurotoxicity. Our epitope mapping of gp41 induction suggests that there may be a putative neurotoxic domain of gp41 that leads to the induction of iNOS. Through dose-response relationships we were able to identify a region of gp41 that is extremely potent 

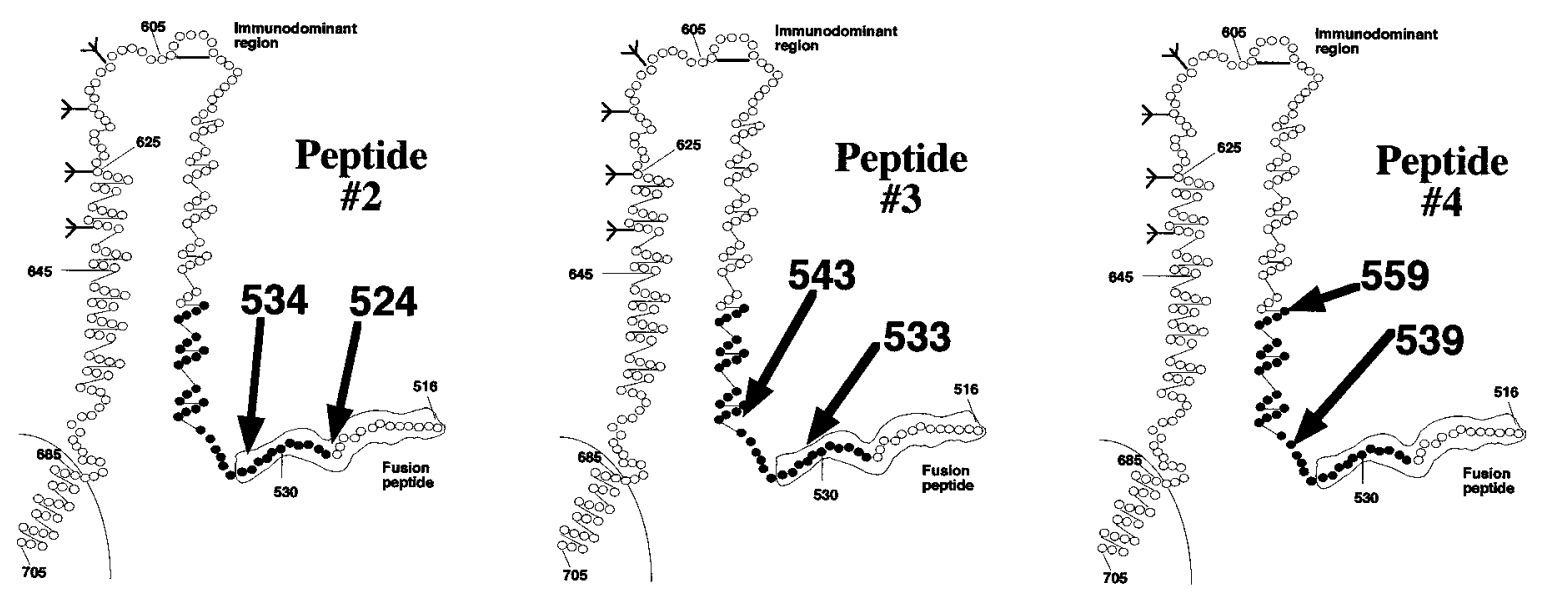

Figure 3. Epitope mapping of gp41 induction of iNOS reveals a neurotoxic domain. Based on the dose-response relationships of induction of iNOS protein, we have designated amino acids 530-559, which are contained within peptides 2 (amino acids 534-524), 3 (amino acids 543-533), and 4 (amino acids 559-539), as the neurotoxic domain (-). This domain lies adjacent to the putative fusion peptide domain of gp41.

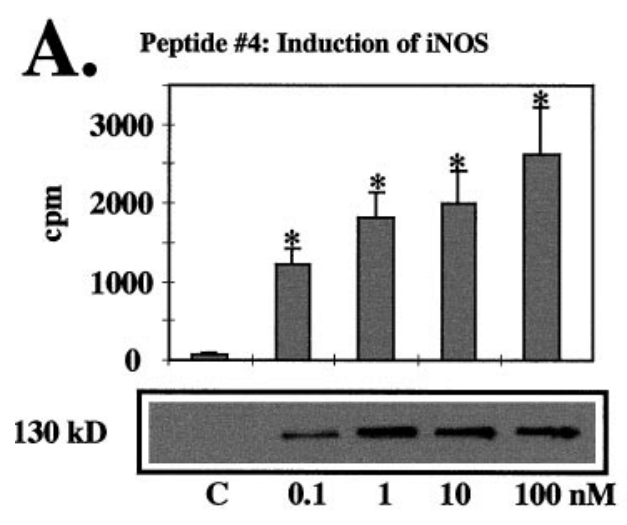

B.

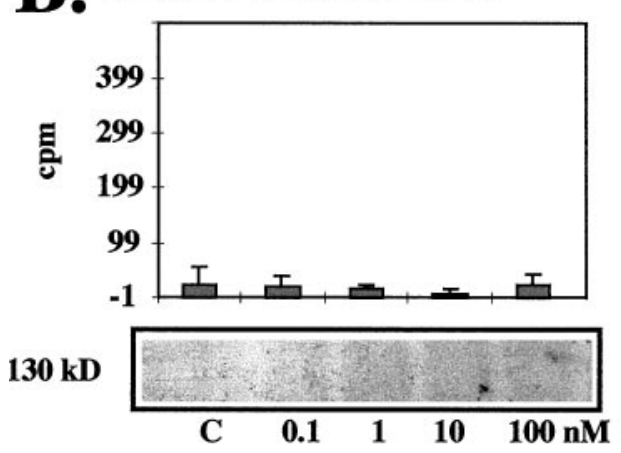

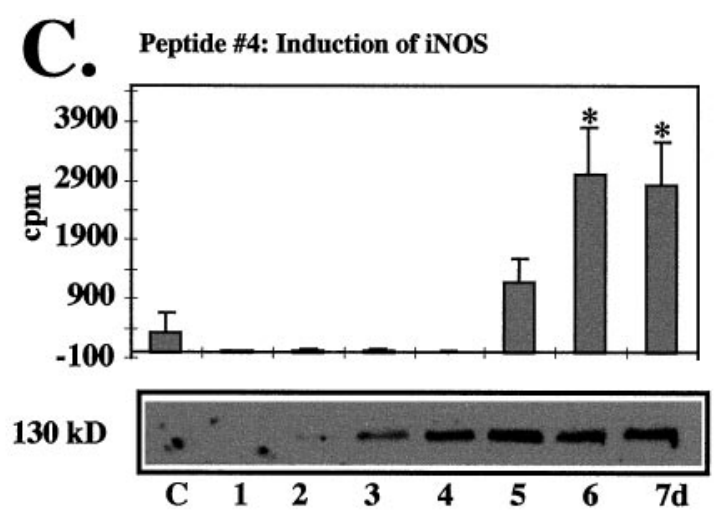

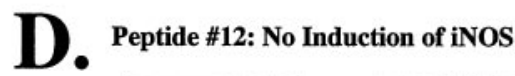

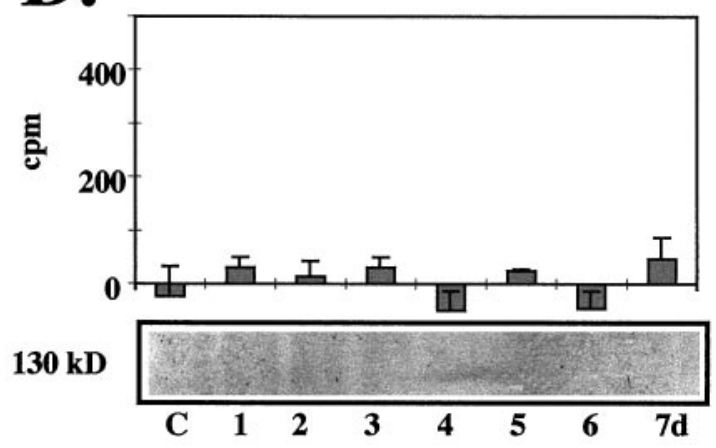

Figure 4. Active gp41 peptide 4 induces iNOS protein and activity. $A$, Rodent mixed cortical cultures were treated with $0.1,1,10$, and 100 nM peptide 4 or peptide $12(B)$ and assessed for NOS activity and protein on day 7 of exposure. $C$, Similar cultures were treated with 100 nM peptide 4 or peptide $12(D)$ and assessed for NOS activity and protein each day for a $7 \mathrm{~d}$ period. Untreated control cultures $(C)$ were also examined. Catalytic activity $(\mathrm{cpm})$ assessments are means \pm SEM for $n \geq 3$ experiments. For each set of data, significance was determined by a one-way ANOVA with differences between groups ascertained by Fisher's PLSD ANOVA post hoc test. $A, F=9.00,{ }^{*} p \leq 0.02 . B, F=0.18, p=0.95 . C, F=3.96,{ }^{*} p \leq 0.02 . D, F=1.92, p=0.13$.

in inducing iNOS in rodent cultures. This region of gp41 corresponds to amino acids 530-559.

We cannot exclude the possibility that the protection against gp41 in iNOS $^{-1-}$ cortical cultures is caused by compensatory processes attributable to the gene-targeting strategy. However, we believe that the absence of gp41 toxicity truly reflects the absence of iNOS and NO formation and is not caused by a general lack of response to neurotoxic agents because the $\mathrm{iNOS}^{-1-}$ cortical cul- tures are susceptible to glutamate-mediated excitotoxicity (our unpublished observations). In addition, our results do not necessarily exclude the role of other host factors, particularly cytokines such as TNF- $\alpha$, although TNF- $\alpha$ is likely to act upstream of iNOS in the death cascade.

Recently the crystal structure of gp41 has been determined (Chan et al., 1997). gp41, a trimer of molecules, has an $\alpha$-helical coiled coil structure with an extracellular amino terminus tip. The 


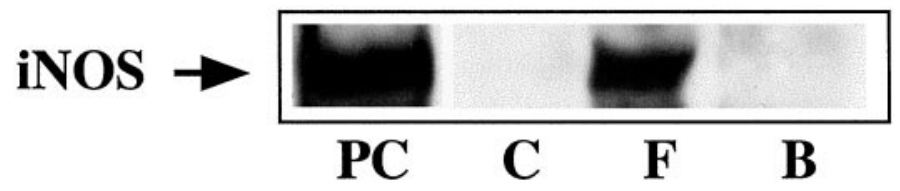

Figure 5. Alternatively synthesized gp41 peptide 4 induces iNOS protein. Rodent mixed cortical cultures were treated with $100 \mathrm{~nm}$ peptide 4 $(F$, forward sequence) from a different peptide synthesis facility or a reverse peptide 4 ( $B$, backward sequence), harvested on day 7 of exposure and assessed for iNOS protein via immunoblot analysis. Untreated control cultures $(C)$ were also assessed. Positive controls $(P C)$ were obtained from rodent glial cultures stimulated with $100 \mathrm{ng} / \mathrm{ml}$ lipopolysaccharide.

C-terminal $\alpha$-helix packs antiparallel against the outside of the coiled coil placing the amino and $\mathrm{C}$ termini near each other. Based on our epitope mapping, the neurotoxic domain of gp41 is located near the amino terminal fusion peptide at a site where the gp41 would be in close contact with the cell surface. Our current understanding of HIV-1 entry into target cells is that at least two cell surface molecules are necessary (Zhang et al., 1996). HIV-1 viral strains use the CD4 receptor as the primary virus receptor through high-affinity interactions with the gp120 viral envelope protein. However, CD4 alone is not sufficient for viral entry. At least one additional surface protein, a co-receptor, is required (Alkhatib et al., 1996; Deng et al., 1996; Dragic et al., 1996). Numerous co-receptors of the chemokine receptor family have been identified, and these various receptors determine cell typespecific tropisms for HIV-1 infection. A model of HIV-1 interactions with CD4 and chemokine co-receptors is depicted in Figure 7. The close proximity of the putative neurotoxic domain of gp41 to the fusion peptide places it in an ideal position for cell/cell interaction. Our experiments suggest that gp41 is eliciting the induction of iNOS through potential cell surface receptors or binding sites because the induction of iNOS by gp41 and its neurotoxic domain peptides is dose dependent and saturable and occurs at physiologically relevant concentrations. Consistent with the notion that this putative neurotoxic domain is important for gp41 interactions with cell surface receptors is the observation that a peptide from this region is able to completely block HIV1-mediated fusion (Kliger et al., 1997).

Recent studies have reported that the C-terminal fusion domain of gp41 can create pores and thus elicit nonspecific toxicity. Our observations that the fusion peptide region of gp41 is inactive in inducing iNOS excludes the pore-forming region of gp41 as mediating the induction of iNOS and subsequent cell death. The induction of iNOS by recombinant gp41 as well as neurotoxic domain peptides has been described in human mixed glial cultures with a response identical to that observed in our rodent cultures (Koka et al., 1995a,b). Furthermore, gp41 can induce iNOS- and NO-dependent toxicity in human neural cell aggregate cultures that develops over $7 \mathrm{~d}$ and peaks at day 14 of exposure (L. Pulliam, personal communication). These findings suggest that the mechanism by which gp41 stimulates iNOS and induces cell death is similar in rodent and human tissue and that production of NO from iNOS is toxic to human cells.

It is unlikely that glycosylation is required for biological activity of gp41 because the four or five potential glycosylation sites on gp41 are located more than 50 amino acids away from the region we found to be critical in eliciting NO-dependent neurotoxicity. Consistent with this notion is the observation that HIV-1mediated fusion does not require glycosylation of gp41 (Perrin et al., 1998) and the previous observations that recombinant gp41
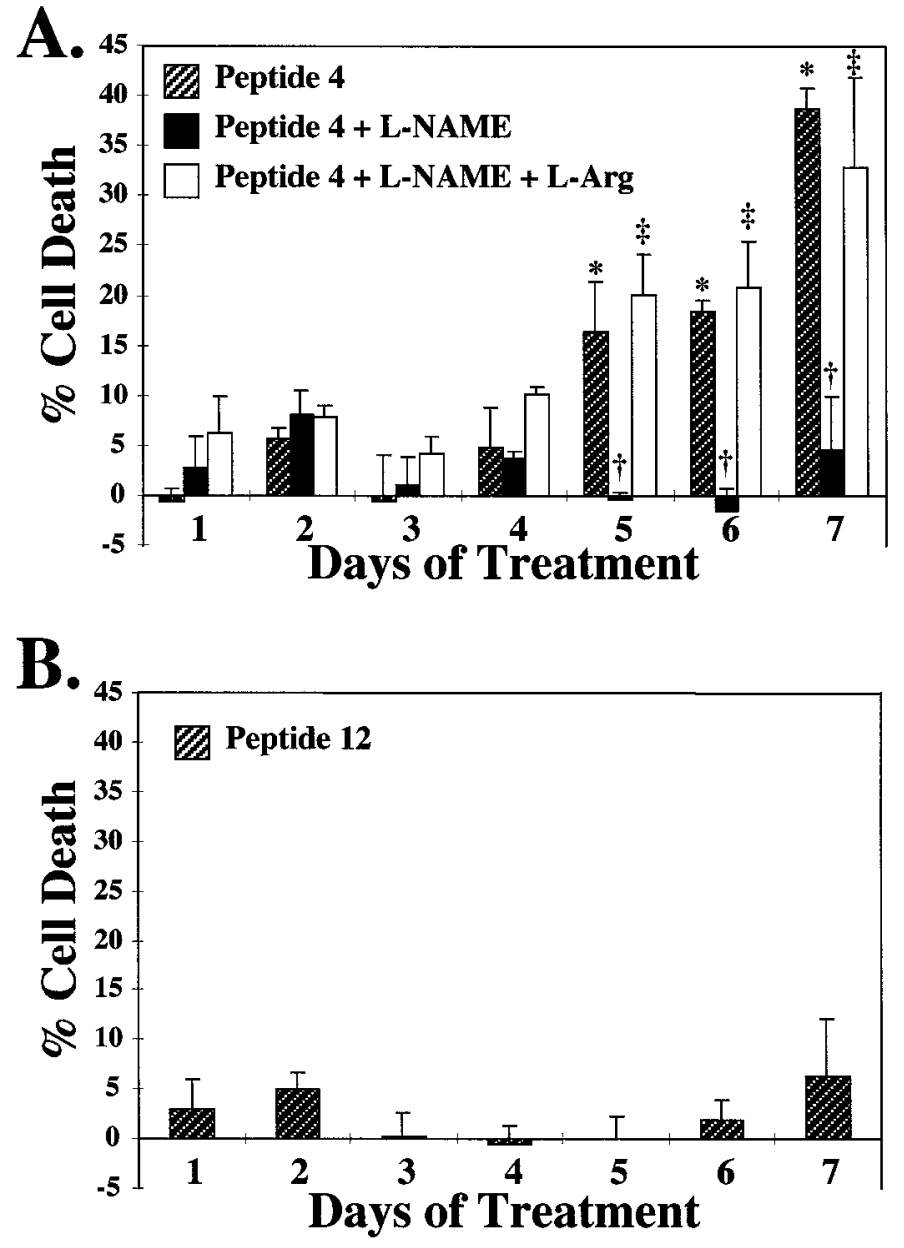

Figure 6. NOS inhibitors block neuronal cell death elicited by a gp41 neurotoxic domain peptide. $A$, Rodent mixed cortical cultures were treated with $100 \mathrm{nM}$ peptide 4 in the presence or absence of $500 \mu \mathrm{M}$ L-NAME, a competitive NOS inhibitor, $\pm 5 \mathrm{~mm} \mathrm{L-Arg.} \mathrm{Cell} \mathrm{death} \mathrm{was}$ assayed by microscopic examination with computer-assisted cell counting after staining of all nuclei with $1 \mu \mathrm{g} / \mathrm{ml}$ Hoescht 33342 and staining of dead cell nuclei with $7 \mu \mathrm{M}$ propidium iodide (Gonzalez-Zulueta et al., 1998). Percentage of cell death was assessed on each day for a $7 \mathrm{~d}$ period and normalized to untreated control cultures. $B$, Similar cultures were treated with $100 \mathrm{~nm}$ peptide 12 and similarly assayed for cell death over a $7 \mathrm{~d}$ period. For all conditions, at least three separate experiments with four separate wells were performed, with a minimum of 15,000-20,000 neurons counted per data point. Data are means \pm SEM for $n \geq 3$ experiments. For each set of data, significance was determined by ANOVA repeated measures, with differences between groups ascertained by Fisher's PLSD ANOVA post hoc test. $A, F=3.63,{ }^{*} p \leq 0.01$ for Peptide 4 (day 1 ) versus Peptide 4 (days 5, 6, 7); $\downarrow p \leq 0.01$ for Peptide 4 (day 5) versus Peptide $4+$ L-NAME (day 5), Peptide 4 (day 6 ) versus Peptide $4+$ L-NAME (day 6), Peptide 4 (day 7) versus Peptide $4+$ L-NAME (day 7); $\ddagger p \leq 0.01$ for Peptide $4+$ L-NAME (day 5) versus Peptide $4+$ L-NAME + L-Arg (day 5), Peptide $4+$ L-NAME (day 6 ) versus Peptide $4+$ L-NAME + L-Arg (day 6 ), Peptide $4+$ L-NAME (day 7) versus Peptide $4+\mathrm{L}-\mathrm{NAME}+\mathrm{L}-\mathrm{Arg}$ (day 7).

behaves in a manner identical to full-length glycosylated gp41 in inducing pro-inflammatory cytokines and cell death (Koka et al., 1995a,b).

Recently, we observed a correlation between gp41 levels and severity and rate of progression of HAD (Adamson et al., 1996b, 1998). Our observations that gp41 can induce a cascade of events that is toxic to neurons suggests that gp41 may play an important role in the pathogenesis of HAD. Consistent with this notion is 


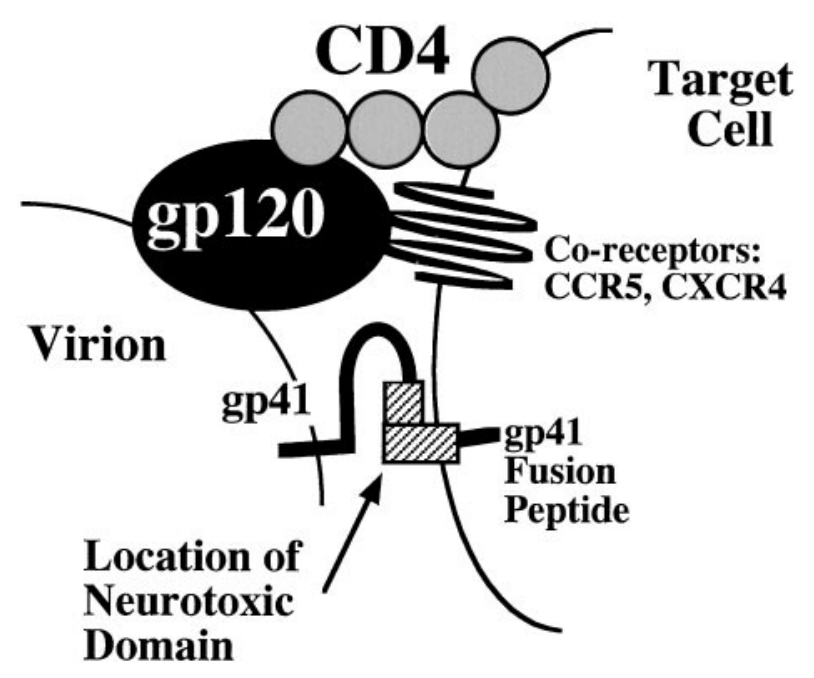

Figure 7. Schematic diagram of the relationship of HIV-1 coat proteins to extracellular receptors. The close proximity of the putative neurotoxic domain of gp41 to the fusion peptide places it in an ideal position for cell/cell interaction.

the observation that the localization of neuroinflammatory cytokines is in close proximity to gp41-expressing cells (Nuovo and Alfieri, 1996). In addition, markers of apoptosis in postmortem studies of HAD and simian immunodeficiency virus (SIV)infected monkeys is in close proximity to gp41 expression (Adamson et al., 1996a). The correlation of gp41 levels and severity of HAD has been observed in HIV-1-infected children (Dickson et al., 1989) and adults (Rostasy et al., 1998). In SIV-infected macaques, neurological disease also correlates with gp41 expression (Zink et al., 1997).

The ability of NOS inhibitors and the importance of iNOS in gp41 neurotoxicity and the correlation of gp41 levels with severity and rate of progression of HAD suggest that inhibitors of iNOS might have therapeutic potential in the treatment of HIV-1associated neurological illness. The identification of a neurotoxic domain of gp41 may direct future studies toward identification of cell surface receptors or binding sites and identification of potential therapeutic agents that may prevent this interaction and offer therapeutic benefits.

\section{REFERENCES}

Adamson DC, Dawson TM, Zink MC, Clements JE, Dawson VL (1996a) Neurovirulent simian immunodeficiency virus infection induces neuronal, endothelial and glial apoptosis. Mol Med 2:417-428.

Adamson DC, Wildemann B, Sasaki M, Glass JD, McArthur JC, Christov VI, Dawson TM, Dawson VL (1996b) Immunologic NO synthase: elevation in severe AIDS dementia and induction by HIV-1 coat protein, gp41. Science 274:1917-1921.

Adamson DC, McArthur JC, Dawson TM, Dawson VL (1999) Course of HIV-associated dementia: correlations with gp41, iNOS and macrophage/microglial activation. Mol Med, in press.

Alkhatib G, Combadiere C, Broder CC, Feng Y, Kennedy PE, Murphy PM, Berger EA (1996) CC CKR5: a RANTES, MIP-1alpha, MIP1beta receptor as a fusion cofactor for macrophage-tropic HIV-1. Science 272:1955-1958.

Barcova M, Kacani L, Speth C, Dierich MP (1998) gp41 envelope protein of human immunodeficiency virus induces interleukin (IL)-10 in monocytes, but not in B, T, or NK cells, leading to reduced IL-2 and interferon-gamma production. J Infect Dis 177:905-913.

Bird C, Burke J, Gleeson PA, McCluskey J (1990) Expression of human immunodeficiency virus 1 (HIV-1) envelope gene products transcribed from a heterologous promoter. Kinetics of HIV-1 envelope processing in transfected cells. J Biol Chem 265:19151-19157.
Brenneman DE, Westbrook GL, Fitzgerald SP, Ennist DL, Elkins KL, Ruff MR, Pert CB (1988) Neuronal cell killing by the envelope protein of HIV and its prevention by vasoactive intestinal peptide. Nature 335:639-642.

Chan DC, Fass D, Berger JM, Kim PS (1997) Core structure of gp41 from the HIV envelope glycoprotein. Cell 89:263-273.

Dawson VL, Dawson TM, Uhl GR, Snyder SH (1993) Human immunodeficiency virus type 1 coat protein neurotoxicity mediated by nitric oxide in primary cortical cultures. Proc Natl Acad Sci USA 90:3256-3259.

Dawson VL, Kizushi VM, Huang PL, Snyder SH, Dawson TM (1996) Resistance to neurotoxicity in cortical cultures from neuronal nitric oxide synthase-deficient mice. J Neurosci 16:2479-2487.

Deng H, Liu R, Ellmeier W, Choe S, Unutmaz D, Burkhart M, Di Marzio P, Marmon S, Sutton RE, Hill CM, Davis CB, Peiper SC, Schall TJ, Littman DR, Landau NR (1996) Identification of a major co-receptor for primary isolates of HIV-1. Nature 381:661-666.

Dickson DW, Belman AL, Park YD, Wiley C, Horoupian DS, Llena J, Kure K, Lyman WD, Morecki R, Mitsudo S (1989) Central nervous system pathology in pediatric AIDS: an autopsy study. APMIS [Suppl] 8:40-57.

Dickson DW, Lee SC, Mattiace LA, Yen SC, Brosnan C (1993) Microglia and cytokines in neurologic disease, with special reference to AIDS and Alzheimer's disease. Glia 7:75-83.

Dragic T, Litwin V, Allaway GP, Martin SR, Huang Y, Nagashima KA, Cayanan C, Maddon PJ, Koup RA, Moore JP, Paxton WA (1996) HIV-1 entry into CD4+ cells is mediated by the chemokine receptor CC-CKR-5. Nature 381:667-673.

Earl PL, Moss B, Doms RW (1991) Folding, interaction with GRP78$\mathrm{BiP}$, assembly, and transport of the human immunodeficiency virus type 1 envelope protein. J Virol 65:2047-2055.

Everall IP, Luthert PJ, Lantos PL (1991) Neuronal loss in the frontal cortex in HIV infection. Lancet 337:1119-1121.

Glass JD, Fedor H, Wesselingh SL, McArthur JC (1995) Immunocytochemical quantitation of human immunodeficiency virus in the brain: correlations with dementia. Ann Neurol 38:755-762.

Gonzalez-Zulueta M, Ensz LM, Mukhina G, Lebovitz RM, Zwacka RM, Engelhardt JF, Oberley LW, Dawson VL, Dawson TM (1998) Manganese superoxide dismutase protects nNOS neurons from NMDA and nitric oxide-mediated neurotoxicity. J Neurosci 18:2040-2055.

Haseltine WA (1989) Development of antiviral drugs for the treatment of AIDS: strategies and prospects. J Acquir Immune Defic Syndr Hum Retrovirol 2:311-334.

Hill JM, Mervis RF, Avidor R, Moody TW, Brenneman DE (1993) HIV envelope protein-induced neuronal damage and retardation of behavioral development in rat neonates. Brain Res 603:222-233.

Janssen RS, Nwanyanwu OC, Selik RM, Stehr-Green JK (1992) Epidemiology of human immunodeficiency virus versus encephalopathy in the United States. Neurology 42:1472-1476.

Kliger Y, Aharoni A, Rapaport D, Jones P, Blumenthal R, Shai Y (1997) Fusion peptides derived from the HIV type 1 glycoprotein 41 associate within phospholipid membranes and inhibit cell-cell fusion. Structurefunction study. J Biol Chem 272:13496-13505.

Koka P, He K, Camerini D, Tran T, Yashar SS, Merrill JE (1995a) The mapping of HIV-1 gp160 epitopes required for interleukin-1 and tumor necrosis factor alpha production in glial cells. J Neuroimmunol 57:179-191.

Koka P, He K, Zack JA, Kitchen S, Peacock W, Fried I, Tran T, Yashar SS, Merrill JE (1995b) Human immunodeficiency virus type 1 envelope proteins induce interleukin 1, tumor necrosis factor alpha, and nitric oxide in glial cultures derived from fetal, neonatal, and adult human brain. J Exp Med 182:941-951.

Kure K, Lyman WD, Weidenheim KM, Dickson DW (1990a) Cellular localization of an HIV-1 antigen in subactute AIDS encephalitis using an improved double-labelling immunohistochemistry method. Am J Pathol 136:1085-1092.

Kure K, Weidenheim KM, Lyman WD, Dickson DW (1990b) Morphology and distribution of HIV-1 gp41-positive microglia in subacute AIDS encephalitis. Pattern of involvement resembling a multisystem degeneration. Acta Neuropathol 80:393-400.

Lipton SA, Sucher NJ, Kaiser PK, Dreyer EB (1991) Synergistic effects of HIV coat protein and NMDA receptor-mediated neurotoxicity. Neuron 7:111-118.

Masliah E, Ge N, Morey M, DeTeresa R, Terry RD, Wiley CA (1992) 
Cortical dendritic pathology in human immunodeficiency virus encephalitis. Lab Invest 66:285-291.

Merrill JE, Chen ISY (1991) HIV-1, macrophages, glial cells, and cytokines in AIDS nervous system disease. FASEB J 5:2391-2396.

Merrill JE, Koyanagi Y, Zack J, Thomas L, Martin F, Chen IS (1992) Induction of interleukin-1 and tumor necrosis factor alpha in brain cultures by human immunodeficiency virus type 1 . J Virol 66:2217-2225.

Navia BA, Jordan BD, Price RW (1986) The AIDS dementia complex: 1. Clinical features. Ann Neurol 19:517-524.

Nuovo GJ, Alfieri ML (1996) AIDS dementia is associated with massive, activated HIV-1 infection and concomitant expression of several cytokines. Mol Med 2:358-366.

Perrin C, Fenouillet E, Jones IM (1998) Role of gp41 glycosylation sites in the biological activity of human immunodeficiency virus type 1 envelope glycoprotein. Virology 242:338-345.

Price RW, Brew B, Sidtis J, Rosenblum M, Scheck AC, Cleary P (1988) The brain in AIDS: central nervous system HIV-1 infection and AIDS dementia complex. Science 239:586-592.

Rosenblum M (1990) Infection of the central nervous system by the human immunodeficiency virus type 1. Pathobiol Annu 25:117-169.

Rostasy K, Monti L, Kneissl M, Bell J, Hedreen J, Navia B (1998) Proinflammatory mediators and HIV infection in the basal ganglia: their pathogenetic relationship to the AIDS dementia complex. Neuroscience of HIV Infection 1:30

Sabatier J, Vives E, Mabrouk K, Benjouad A, Rochat H, Duval A, Hue B, Bahraoui E (1991) Evidence for neurotoxic activity of tat from human immunodeficiency virus type 1. J Virol 65:961-967.

Samdani AF, Newcamp C, Resink A, Facchinetti F, Hoffman BE, Dawson VL, Dawson TM (1997) Differential susceptibility to neurotoxicity mediated by neurotrophins and neuronal nitric oxide synthase. J Neurosci 17:4633-4641.

Seilhean D, Kobayashi K, He Y, Uchihara T, Rosenblum O, Katlama C, Bricaire F, Duyckaerts C, Hauw JJ (1997) Tumor necrosis factoralpha, microglia and astrocytes in AIDS dementia complex. Acta Neuropathol (Berl) 93:508-517.
Toggas SM, Masliah E, Rockenstein EM, Rall GF, Abraham CR, Mucke L (1994) Central nervous system damage produced by expression of the HIV-1 coat protein gp120 in transgenic mice. Nature 367:188-193.

Watkins BA, Dorn HH, Kelly WB, Armstrong RC, Potts BJ, Michaels F, Kufta CV, Dubois-Dalcq M (1990) Specific tropism of HIV-1 for microglial cells in primary human brain cultures. Science 249:549-553.

Werner T, Ferroni S, Saermark T, Brack-Werner R, Banati RB, Mager R, Steinaa L, Kreutzberg GW, Erfle V (1991) HIV-1 nef protein exhibits structural and functional similarity to scorpion peptides interacting with $\mathrm{K}+$ channels. AIDS 5:1301-1308.

Wesselingh S, Power C, Glass J, Tyor WR, McArthur JC, Farber JM, Griffin JW, Griffin DE (1993) Intracerebral cytokine mRNA expression in AIDS dementia. Ann Neurol 33:576-582.

Wiley CA, Schrier RD, Nelson JA, Lampert PW, Oldstone MB (1986) Cellular localization of human immunodeficiency virus infection within the brains of acquired immune deficiency syndrome patients. Proc Natl Acad Sci USA 83:7089-7093.

Wiley CA, Masliah E, Morey M, Lemere C, DeTeresa R, Grafe M, Hansen L, Terry R (1991) Neocortical damage during HIV infection. Ann Neurol 29:651-657.

Willey RL, Bonifacino JS, Potts BJ, Martin MA, Klausner RD (1988) Biosynthesis, cleavage, and degradation of the human immunodeficiency virus 1 envelope glycoprotein gp160. Proc Natl Acad Sci USA 85:9580-9584.

Willey RL, Shibata R, Freed EO, Cho MW, Martin MA (1996) Differential glycosylation, virion incorporation, and sensitivity to neutralizing antibodies of human immunodeficiency virus type 1 envelope produced from infected primary T-lymphocyte and macrophage cultures. J Virol 70:6431-6436.

Zhang L, Huang Y, He T, Cao Y, Ho DD (1996) HIV-1 subtype and second-receptor use. Nature 383:768.

Zink MC, Amedee AM, Mankowski JL, Craig L, Didier P, Carter DL, Munoz A, Murphey-Cobb M, Clements JE (1997) Pathogenesis of SIV encephalitis: selection and replication of neurovirulent SIV. Am J Pathol 151:793-803. 